\title{
Low Natural Killer Cell Activity
}

National Cancer Institute

\section{Source}

National Cancer Institute. Low Natural Killer Cell Activity. NCI Thesaurus. Code C119998.

A decrease in the ability of peripheral mononuclear blood cells to lyse $\mathrm{MHC}$ I deficient target cells either due to low numbers of natural killer cells, or a reduction of their lytic activity. 